\title{
PENGEMBANGAN MEDIA E-LEARNING BERBASIS TWITTER PADA MATERI BIOLOGI STRUKTUR DAN FUNGSI JARINGAN TUMBUHAN
}

\author{
Maryamah $^{1)}$; Evi Roviati ${ }^{2)}$ \\ 1).Fakultas Ilmu Tarbiyah dan Keguruan/Tadris IPA Biologi A /IAIN Syekh Nurjati Cirebon; mm0979921@ gmail.com \\ 2).Fakultas Ilmu Tarbiyah dan Keguruan/Tadris IPA Biologi A /IAIN Syekh Nurjati Cirebon;:evi1roviati@gmail.com
}

\begin{abstract}
This study aims to determine whether Twitter-based e-learning media can be developed as a media for teaching biology on the structure and function of plant tissue. This research method is research and development. The research sample was teenage smartphone users in Walahar Village, Cirebon Regency. The results showed that e-learning based on twitter can be used and developed as a medium of teaching materials on the structure and function of plant networks.
\end{abstract}

Keywords: e-learning media; Twitter; Structure and function of plant tissue

\section{ABSTRACT}

Penelitian ini bertujuan untuk mengetahui apakah media e-learning berbasis twitter dapat dikembangkan sebagai media bahan ajar biologi pada materi struktur dan fungsi jaringan tumbuhan. Metode penelitian ini adalah penelitian dan pengembangan. Sampel penelitian adalah remaja pengguna smartphone di Desa Walahar Kabupaten Cirebon. Hasil penelitian diperoleh bahwa elearning berbasis twitter dapat digunakan dan dikembangkan sebagai media bahan ajar pada materi Struktur dan fungsi jaringan tumbuhan.

Keywords: Media e-learning; Twitter; Struktur dan fungsi jaringan tumbuhan

\section{PENDAHULUAN}

Tuntutan manusia terhadap kebutuhan informasi semakin tinggi merupakan alternatif komunikasi masyarakat modern saat ini. Komunikasi mengakibatkan dunia tidak lagi mengenal batas, jarak, ruang, dan waktu akibat dari peningkatan informasi, dan teknologi. Informasi penting tentang fenomena kejadian di belahan dunia lain dapat dengan mudah diakses seseorang tanpa harus berada di tempat tersebut. Hanya dengan seperangkat komputer yang

memiliki konektivitas internet, informasi dapat diperoleh dalam hitungan detik tanpa harus memakan waktu berjam-jam.

$$
\text { Perangkat mobile mempunyai }
$$
beberapa keunggulan yang berbasiskan media pembelajaran. Keunggulan dari perangkat mobile antara lain mudah dibawa, dapat terhubung kejaringan kapan saja dan di mana saja, lebih fleksibel dalam mengakses sumber belajar, kedekatan komunikasi, peserta didik dapat terlibat dan aktif. Harga yang murah dan kemudahan menjadi keunggulan utama. Dukungan dari beberapa pihak merupakan 
kemudahan dalam membuat aplikasi edukatif.

Media pembelajaran yang akan digunakan merupakan sebuah aplikasi android yang akan menampilkan materi pembelajaran. Materi pembelajaran yang ditampilkan pada aplikasi android ini adalah materi Struktur dan Fungsi Jaringan Tumbuhan. Melalui pengetahuan dan pengalaman yang diperoleh dalam proses pembelajaran ini peserta didik memiliki pengetahuan yang baik terhadap materi Struktur dan Fungsi Jaringan Tumbuhan dan dapat dipahami dalam proses pembelajaran di kelas.

Penggunaan media pembelajaran yang tepat dalam proses pembelajaran menjadi salah satu factor tercapainya tujuan pembelajaran. Media pembelajaran juga dapat membantu peserta didik untuk melibatkan lebih banyak inderanya dalam belajar seperti yang dikemukakan Asik indan Daningsih (2018) bahwa semakin banyak indera danger akan peserta didik yang terlibat dalam proses belajar, semakin mudah peserta didik dapat belajar mendefinisikan makna. Dibandingkan jika guru hanya memberikan informasi secara verbal, media pembelajaran yang melibatkan lebih banyak indera akan lebih mampu menciptakan kebermaknaan belajar bagi diri peserta didik.

Media pembelajaran yang berbasiskan perangkat mobile mempunyai beberapa keunggulan. Keunggulan dari perangkat mobile antara lain mudah dibawa, dapat terhubung kejaringan kapan saja dan di mana saja, lebih fleksibel dalam mengakses sumber belajar, kedekatan komunikasi, peserta didik dapat terlibat dan aktif. Kemudahan dan harga yang murah menjadi keunggulan utama. Kemudahan dalam membuat aplikasi edukatif juga telah mendapat dukungan dari beberapa pihak.

Perbedaan facebook dan twitter ialah kalau Facebook Membatasi penggunanya mengirim status facebook hingga 400 kata lebih, tetapi jika twitter hanya membolehkan 140 kata. Twitter didirikan dan diresmikan pada tahun 2006 tepatnya pada bulan maret. Didirikan oleh Jack Dorsey. Setiap orang di dunia sudah sangat mengenal jejaring Sosial Twitter. Bahkan di Tahun 2014 ini Twitter menjadi salah satu dari 5 besar situs yang paling sering dikunjungi oleh banyak orang (Gulo, 2012). Setiap orang di dunia sudah sangat mengenal jejaring Sosial Twitter.

Twitter baru dibuka untuk umum pada juli 2006. sudah ada lebih dari 400 rb Kicauan setiap harinya pada 2007, Pada tahun 2010 sudah ada lebih dari 75.000 Aplikasi di twitter. Perusahaan twitter bekerja sama dengan beberapa perusahaan yang ternama seperti Google, Bing, Yandex dan Perusahaan lainnya. Twitter memunculkan banyak fitur baru ketika sudah terkenal di mata penggunanya (Gulo, 2012). 
Dalam materi pembelajaran biologi tentang struktur dan fungsi jaringan tumbuhan disaat pandemi seperti ini tidak dapat dilakukan secara langsung, pada materi ini diperlukan media penujang atau sarana prasarana yang memadai

\section{METODE PENELITIAN}

Jenis penelitian yang digunakan dalam penelitian ini adalah jenis penelitian pengembangan (Research \& Development). Metode penelitian dan pengembangan adalah metode penelitian yang digunakan untuk menghasilkan produk tertentu dan validitas produk tersebut (Sugiyono, 2010). Penelitian dan Pengembangan (Research and Development /R\&D) merupakan metode penelitian yang digunakan untuk mengembangkan atau memvalidasi produk yang digunakan dalam pendidikan dan pembelajaran (Yunita, 2017). Media yang dikembangkan adalah vidio media tiga dimensi model kayu penampang jaringan tumbuhan pada materi struktur dan fungsi jaringan tumbuhan dan menentukan kualitas media pembelajaran tersebut melalui pengujian validitas, praktikalitas dan efektivitas.

Sasaran penelitian yang dipilih adalah remaja. Alasan dipilihnya remaja ini adalah karena tingginya pengguna media sosial twitter dikalangan remaja dan karena tingginya kepemilikan smartphone di kalangan remaja tersebut.

\section{Analisis Data}

Data dan informasi yang diperoleh dari penelitian, di intrepretasikan secara kuantitatif deskriptif dengan menggabungkan katagori katagori yang ada untuk membuat deskriptif kuantitatif. Datadata yang diperoleh melalui kuisioner disajikan ke dalam tabel-tabel frekuensi untuk menjelaskan kecenderungankecenderungan umumdan selanjutnya akan dianalisa secara Deskriptif Kuantitatif, berdasarkan hasil wawancara mendalam dan kajian kepustakaan yang relevan.

\section{HASIL DAN PEMBAHASAN}

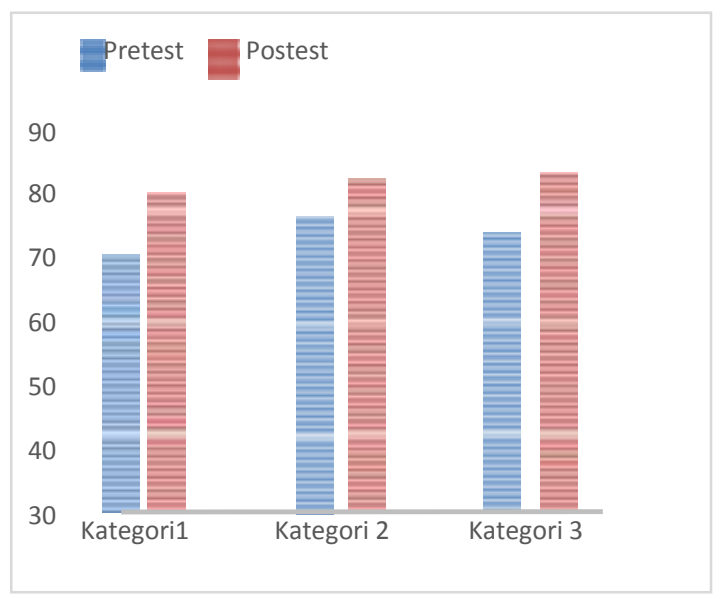

Gambar 1. Respon remaja SMA tehadap materi struktur dan fungsi jaringan tumbuhan dalam media twitter.

Berdasarkan Gambar 1 bahwa respon remaja terhadap materi struktur dan fungsi jaringan tumbuhan dalam media twitter mempermudah interaksi antara peserta didik dengan bahan/materi pelajaran. . Guru dapat memberi kesempatan dan mengakses bahan ajar maupun soal-soal ujian melalui media twitter dalam rentangan waktu tertentu pula. 
Salah satu media pembelajaran yang diharapkan dapat menciptakan suasana belajar yang menarik dan kondusif yaitu dengan penggunaan media mobile learning berbasis twitter. Menggunakan media pembelajaran tersebut diharapkan dapat memberikan pembaharuan dalam proses pembelajaran di kelas. Media mobile learning berbasis twitter ini melengkapi buku elektronik yang sudah ada, sehingga mampu mengakomodasi semua kegiatan pembelajaran interaktif seperti mendengarkan, membaca, menulis dan juga permainan. Kelemahannya yaitu membutuhkan jumlah perangkat smartphone yang sesuai dengan jumlah peserta didik. Pemilihan media mobile learning berbasis twitter dirasa cocok dengan pengembangan Kurikulum saat ini.

Prasetyo (2015) yang menjelaskan bahwa pembelajaran Mobile Learning berbasis twitter berfungsi sebagai suplemen. Peserta didik mempunyai kebebasan memilih, memanfaatkan dan mengakses materi pembelajaran elektronik. Sekalipun sifatnya opsional, peserta didik yang memanfaatkannya tentu akan memiliki tambahan pengetahuan atau wawasan sehingga mampu meningkatkan sikap pemahaman materi biologi peserta didik. Pengguna media sosial bisa mengakses dengan jaringan internet bahkan yang aksesnya lambat sekalipun, tanpa biaya besar, tanpa alat mahal dan dilakukan sendiri tanpa karyawan. Tulisan, gambar, video, grafis, dan berbagai model content lainnya dapat diedit, ditambahkan dan memodifikasi oleh pengguna media sosial dengan bebas.

Media online, dengan para penggunanya bias dengan mudah berpartisipasi, berbagi, dan menciptakan isi meliputi blog, jejaring sosial, wiki, forum dan dunia virtual. Blog, jejaring sosial dan wiki merupakan bentuk media sosial yang paling umum digunakan oleh masyarakat di seluruh dunia dalam media sosial. Pendapat lain mengatakan bahwa media social adalah media online yang mendukung interaksi sosial dan media social menggunakan teknologi berbasis web yang mengubah komunikasi menjadi dialog interaktif. Twitter ialah Jejaring Sosial yang membatasi penggunanya untuk mengirim sebuah tweet dengan batas 140 kata, tidak lebih. Twitter dengan Facebook mempunyai kesamaan dan perbedaan. Kesamaannya ialah Twitter dan Facebook sama-sama layanan Jejaring Sosial yang berguna untuk saling menghubungkan antara pengguna satu dengan pengguna yang lainya (Hasan, 2017).

Kemajuan teknologi sebagai sarana komunikasi melalui media sosial online. Artis dalam negeri maupun luar negeri memiliki situs berita serta akun twitter sehingga membuat setiap penggunanya merasa bahwa twitter menjadi situs media sosial paling utama untuk dikunjungi karena banyaknya informasi yang 
diperoleh dengan cara mengklik tautan yang diupdate. Banyak orang yang memanfaatkan twitter sebagai wadah untuk berdiskusi dan berbagi melalui twit mereka yang berisi berbagaima cam topik mulai dari hiburan, teknologi sampai topik yang berat seperti isu politik. Semuanya dapat di diskusikan dan dibagi bersama secara bebas oleh sesama pengguna jejaring sosial twitter (Rizky,2015).

Media pembelajaran mobile learning berbasis twitter dapat memberdayakan sikap berfikir peserta didik. Hal ini dikarenakan nilai rata-rata pemahaman peserta didik masih rendah hanya berada pada kategori mulai terlihat sebelum menggunakan media pembelajaran mobile learning berbasis twitter. Setelah menggunakan media pembelajaran Mobile Learning berbasis twitter sikap peduli lingkungan peserta didik meningkat menjadi kategori mulai berkembang. Pengembangan media pembelajaran mobile learning berbasis twitter dalam memahami materi struktur dan fungsi jaringan tumbuhan mendapat respon yang sangat baik oleh peserta didik. Selanjutnya menurut Rusman (2013) melalui pembelajaran mobile learning berbasis twitter minat belajar dapat ditingkatkan karena pembelajaran mobile learning berbasis twitter berfungsi sebagai komplemen berarti materi e-learning diprogramkan untuk menjadi materi pengayaan bagi peserta didik di dalam mengikuti kegiatan pembelajaran konvensional. Materi pelajaran yang disajikan guru di kelas bertujuan untuk memantapkan tingkat penguasaan peserta didik. Peserta didik yang mengalami kesulitan dalam memahami materi pelajaran yang disampaikan guru secara tatap muka di kelas dapat mengikuti remedial. Dengan demikian, dapat dikatakan bahwa peserta didik cenderung menggunakan media sosial dalam menyampaikan atau update mengenai kondisi situasi terkini melalui tweet media sosial twitter. Peserta didik menyadari akan dampak negatif dari jejaring sosial twitter, jawaban setuju (S) sebanyak 4 orang dan 4 orang yang sangat setuju (SS) dengan persentase 24\%. Namun sangat disayangkan masih dominannya peserta didik membuka jejaringan sosial dari pada membaca buku, hal ini dapat dilihat dari jawaban peserta didik yang setuju (S) sebanyak 6 orang dan sangat setuju (SS) sebanyak 4 orang, dengan persentase $24 \%$. Kemudian untuk update status dijejaring sosial saat proses belajar mengajar, peserta didik yang menjawab sangat tidak setuju (STS) sebanyak 1 orang dan setuju (S) sebanyak 5 orang, dengan persentase $15 \%$. Sementara untuk pernyataan lebih mudah berkomunikasi di jejaring sosial dari pada di dunia nyata, banyak peserta didik yang menjawab tidak tahu (TT) sebanyak 6 
orang dengan persentase $15 \%$. Terakhir dari pernyataan mengenai lebih aktif di jejaring sosial dari pada dunia nyata, peserta didik menjawab Sangat sangat tidak setuju (STS) sebanyak 5 orang dengan persentase $12 \%$. motif hiburan peserta didik dalam media sosial twitter adalah menggunakan twitter untuk menghilangkan suntuk saat belajar, dengan jawaban responden siswa sebanyak 17 orang atau persentase $41 \%$, sementara jawaban responden yang menggunakan twitter untuk curhat dalam menghibur diri sebanyak 15 orang atau persentase $37 \%$, dan untuk responden yang menjawab mengenai twitter tempat berkomunikasi untuk mencari pasangan/kenalan baru sebanyak sebanyak 9 orang dengan persentase $22 \%$. Dengan demikian motif menggunakan media sosial twitter ialah, untuk menghilangkan suntuk saat belajar dengan persentase $41 \%$.

Perkembangan media memang seperti tidak bias lagi dipisahkan oleh kehidupan seseorang saat ini. Seakan akan media "memaksa" untuk menggunakannya demi kelangsungan hidup. Era modern saat ini dituntut untuk tau segala hal, dan dengan menggunakan media untuk masalah politik, ekonomi, sosial, bahkan untuk proses pembelajaran. Saat ini media konvensional seperti koran atau pun radio bukanlah menjadi unggulan lagi bagi seseorang yang ingin mendapatkan berita terbaru. Pamor dari koran dan radio menjadi tergeserkan karena hadirnya media baru. Sebut saja twitter, sebuah media baru berjenis micr blogging yang bias memberikan kita kemudahan untuk mendapatkan berita secara cepat dan singkat. Seseorang akan merasa tercukupi kebutuhan dan rasa keingin tahuannya dengan menggunakan media micro blogging twitter ini.

Kini media sosial menjadi kajian dari peneliti, karena media menjadikan seseorang terbuka akan dirinya di hadapan orang lain atau pun dengan orang yang belum dikenal nya, khususnya para kalangan peserta didik sekolah menengah pertama.

Memperluas jaringan pertemanan. Berkat media sosial twitter ini peserta didik menjadi lebih mudah berteman dengan orang lain di seluruh dunia. Meskipun sebagian besar diantaranya tidak pernah bertemu secara langsung. Peserta didik akan termotivasi iuntuk belajar mengembangkan diri melalui teman-teman untuk dijumpai secara online, berinteraksi dan menerima umpan balik satu sama lain.

\section{SIMPULAN DAN SARAN SIMPULAN}

Pengembangan media e-learning berbasis twitter dapat digunakan dan dikembangkan sebagai media bahan ajar pada materi struktur dan fungsi jaringan tumbuhan. 


\section{SARAN}

Guru biologi SMA melakukan menerapkan pembelajaran mobile learning berbasis twitter sebagai alternatif pembelajaran di kelas sehingga peserta didik tidak mudah bosan dan termotivasi untuk mengikuti pelajaran.

\section{UCAPAN TERIMA KASIH}

Terimakasih kepada pihak yang telah membantu dalam menyelesaikan mini riset ini, dan terimakasih juga kepada yang telah membimbing dan membantu dalam pembuatan jurnal ilmiah, semoga dapat bermanfaat bagi penulis maupun pembaca.

\section{DAFTAR PUSTAKA}

Asikin dan Daningsih (2018), Metode Penelitian. Bandung : Alfabeta;

Gulo, 2012, Metode Penelitian, Jakarta : Grassindo;

Hasan Basri. 2017, Peran Media Sosial Twitter Dalam Interaksi Sosial Pelajar Sekolah Menengah Pertama Di Kota Pekanbaru (studi kasus pelajar SMPN 1 kota Pekanbaru), Jom FISIP Volume 4 NO. 2 Oktober 2017;
Prasetyo, Y.D, Yektyastuti, R., Solihah, M., Ikhsan, J. dan Sugiyarto, K. (2015), Pengaruh penggunaan media pembelajaran kimia berbasis aplikasi android terhadap peningkatan motivasi siswa SMA, Seminar Nasional Pendidikan Sains $V$;

Rizky, R. Gustam. 2015, Karakteristik Media Sosial dalam Membentuk Budaya Populer, EJournal Ilmu Komunikasi, Volume 3, Nomor 2, 2015: 224-242;

Rusman, 2013, Metode Penelitian, Jakarta : Grassindo;

Sakti, Yunita Tritika, 2017, Pengembanga Media Tiga Dimensi Anatomi Tumbuhan Materi Struktur dan Fungsi Jarimgan Tumbuhan, Malang: Universitas Muhammadiyah Malang;

Sugiyono, 2010, Metode Penelitian Pendekatan Kuantitatif, Kualitati fdan $R \& D$, Bandung: Alfabeta. 